\title{
Identification of Single Nucleotide Polymorphism on Growth Hormone Gene in Aceh Cattle
}

\author{
E. M. Sari ${ }^{a, *}$, R. R. Noor ${ }^{b}$, C. Sumantri ${ }^{b}$, M. Yunus ${ }^{a}$, Han J. L. ${ }^{c}$, \& Muladno ${ }^{b}$ \\ aDepartment of Animal Production, Faculty of Agriculture, Syiah Kuala University, \\ Jln. Teuku Nyak Arief Banda Aceh 23111, Indonesia \\ ${ }^{b}$ Department of Animal Production and Technology, Bogor Agricultural University \\ Jln. Agatis, Kampus IPB Darmaga, Bogor 16680, Indonesia \\ ${ }^{c}$ CAAS (Chinese Academy of Agricultural Sciences) - ILRI (International Livestock Research Institute) \\ JLLFGR (Joint Laboratory on Livestock and Forage Genetic Resources) Beijing-China \\ (Received 08-11-2012; Reviewed 11-12-2012; Accepted 12-04-2013)
}

\begin{abstract}
This research was aimed to identify the changes of nucleotide (Single Nucleotide Polymorphism) growth hormone gene in the population of Aceh cattle. There were 44 samples of DNA sequenced, and a few samples from Gen Bank (M57764). Based on the analysis using MEGA program, it was identified one new mutation on exon five on $2230 \mathrm{bp}$ in which $\mathrm{C}$ nucleotide turned into $\mathrm{T}$ nucleotide, and this was called Silent Mutation (Leusine-Leusine/ CTC-CTT). The frequency of Single Nucleotide Polymorphism (SNP) genotype on $2230 \mathrm{bp}(\mathrm{C} / \mathrm{T})$ was CC $(0.36)$, TT $(0.14)$ and CT $(0.50)$. The genotype TT was not possessed by Aceh cattle from Saree, but possessed by those from Banda Aceh and Indrapuri. Chi-square test showed not significant differences in allele frequencies for three population. The frequency of genotype SNP on $2291 \mathrm{bp}(\mathrm{A} / \mathrm{C})$ was AC (0.11) and CC (0.89). The frequency of allele C was higher than allele $\mathrm{A}$ and $\mathrm{T}$.
\end{abstract}

Key words: Aceh cattle, SNPs, GH gene

\section{ABSTRAK}

Tujuan penelitian ini untuk mengidentifikasikan perubahan basa nukleotida (Single Nucletide Polymorphism) gen hormon pertumbuhan pada sapi Aceh. Sampel DNA yang berhasil disekuen berjumlah 44 sampel, serta menggunakan sampel sekuen yang berasal dari Gen Bank (M57764). Berdasarkan analisis dengan menggunakan sofware program MEGA, penelitian ini mengidentifikasi adanya satu titik mutasi baru pada ekson lima diposisi $2230 \mathrm{bp}$, yaitu terjadi perubahan basa $\mathrm{C}$ menjadi basa T, yang merupakan Silent Mutation (Leusine-Leusine/ CTC-CTT). Frekuensi genotipe SNP pada posisi $2230 \mathrm{bp}(\mathrm{C} / \mathrm{T})$ adalah CC $(0,36)$, TT $(0,14)$ dan CT $(0,50)$. Genotipe TT tidak dimiliki oleh populasi sapi Aceh yang berasal dari Saree, tetapi dimiliki oleh populasi yang berasal dari Banda Aceh dan Indrapuri. Berdasarkan hasil uji Chi-Square menunjukkan tidak terdapat perbedaan frekuensi alel dari ketiga populasi. Frekuensi genotipe SNP pada posisi 2291 bp $(A / C)$ adalah AC $(0,11)$ dan CC $(0,89)$. Frekuensi alel C memiliki nilai yang lebih tinggi daripada frekuensi alel A dan alel T.

Kata kunci: sapi Aceh, SNPs, gen GH

\section{INTRODUCTION}

Maintain the local livestock resources are important, because it can achieve the sustainable food security for millions of human beings. Besides, maintaining the livestock resources is also able to increase the list of germ plasma as the sources of animal protein. Thus, in order to reduce the extinction speed, especially on the local Indonesian livestock, it is necessary to find the gene

*Corresponding author:

E-mail: ekasari865@yahoo.com information through the efforts of knowing the genetic diversity towards the local livestock.

Aceh cattle is one of Indonesian beef cattle which is suitable to be bred in Indonesia. This type of cattle adapts well to Indonesian environment, tropical climate, and is able to live on the local water and food (Sari et al., 2010). Even though Aceh cattle is able to adapt well, their productivity is still lower than imported ones. By improving the productivity of Indonesian local cattle, it is hoped that the breeders' interest to breed local cattle will increase, so that the population of local cattle is increasing and able to reduce Indonesian dependency on beef and cattle from other countries. 
Bovine growth hormone $(\mathrm{bGH})$ is a single peptide of molecular weight equal to 22-kD secreted from pituitary gland, composed of 190 or 191 amino acids residues and containing Ala or Phe at the N-terminus due to alternative processing of bGH precursor (Dybus, 2002). This gene is approximately $2800 \mathrm{bp}$ with five exons and four introns, and also a part of multiple gene family that contains prolactin and placental lactogens and is located on BTA19, 66cM from centromic marker BM9202 (Zakizadeh et al., 2006). Allelic variations in the structural or regulatory sequences would be interesting from several points of view. Firstly, genetic polymorphism could have possible direct or indirect effect on growth performance. Secondly, variations in introns or flanking sequences have potential usefulness as genetic marker and help the genetic improvement of populations (Ge et al., 2003).

In farm animals, many polymorphisms have been identified in the GH gene, but only a few of these have been precisely characterized for nucleotide changes and positions in the DNA sequence. In bovine, a single nucleotide polymorphism (SNP) in exons 5 (at codon 127) changes Leusine to Valine (CTG to GTG) in GH molecule (Lucy et al., 1993). Ge et al. (2003) used sequencing method on Angus cattle and found three new SNP on promoter area. Zakizadeh et al. (2006) also reported in Iranian cattle. The research of GH gene AluI in Indonesian cattle have been reported in Bali, Madura, and Benggala cattle (Sutarno et al., 2002), West Sumatra Pesisir cattle (Jakaria et al., 2007); Bali cattle (Jakaria \& Noor, 2011), but the research of GH gene AluI in exon 5 in Aceh cattle have never been reported. Based on the description above, it is necessary to carry out a research to identify clearly the position of nucleotide changes of DNA sequence on GH gene exon 5 and to identify the number and SNP allele frequency on Aceh cattle.

\section{MATERIALS AND METHODS}

\section{Blood Sampling, Time, and Place of Research}

The DNA sample used for sequencing was taken from various region in Indonesia: Banda Aceh (9), Saree (12), and Indrapuri (23). The blood sample of Aceh cattle was taken using venojact (EDTA) $5 \mathrm{~mL}$ on vena jugulars, and then it was kept in an ice box for later laboratory analysis. DNA isolation, extraction, and purification were all carried out in Genetics and Animal Breeding Laboratory, Department of Animal Production and Technology, Bogor Agricultural University. GH gene analysis was conducted in Molecular and Genetics Laboratory CAAS (Chinese Academy of Agricultural Sciences) Beijing -China.

\section{Genome DNA Extraction}

Genome DNA extraction was carried out using Sambrook et al. (1989) method which was modified using buffer lysis cell $(400 \mu \mathrm{L} 1 \times$ STE, and $40 \mu \mathrm{L} \mathrm{10 \%} \mathrm{SDS}$ and $10 \mu \mathrm{L}$ proteinase-K). The DNA was then purified using phenol-chloroform method, in which $40 \mu \mathrm{L} 5$ $\mathrm{M} \mathrm{NaCl}$ and $400 \mu \mathrm{L}$ phenol and chloroform iso amyl alcohol (CIAA) was added. The DNA was precipitated using $40 \mu \mathrm{L} 5 \mathrm{M} \mathrm{NaCl}$ and $800 \mu \mathrm{L}$ ethanol absolute. The precipitate was washed once by adding $800 \mu 170 \%$ ethanol, centrifuged with the speed of $12,000 \mathrm{rpm}$ for 5 min, the ethanol was discarded and evaporated. Then, the DNA precipitate was dissolved in $10 \mu \mathrm{L} 80 \%$ TE (Elution buffer).

\section{DNA Amplification}

The DNA was amplified with Polymerase Chain Reaction (PCR). Each PCR reaction was made with the volume of $50 \mu \mathrm{L}$ with the composition of $5 \mu \mathrm{L} 1 \mathrm{x}$ buffer PCR; $4 \mu \mathrm{l}$ dNTP; $1 \mu \mathrm{L}$ Taq DNA Polymerase; $1 \mu \mathrm{L}$ Primer

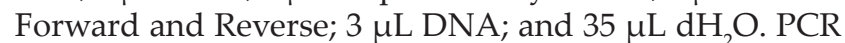
machine used was Gene Amp PCR System 9700 Applied Biosystem. The PCR program was performed for 34 cycles in which the first cycle was at $94{ }^{\circ} \mathrm{C}$ for $5 \mathrm{~min}$ followed by 33 subsequent cycles of denaturation step on $94{ }^{\circ} \mathrm{C}$ for $30 \mathrm{~s}$, and annealing on $59{ }^{\circ} \mathrm{C}$ for $30 \mathrm{~s}$, and extension on $72{ }^{\circ} \mathrm{C}$ for $5 \mathrm{~min}$ and the last cycle extension on $72{ }^{\circ} \mathrm{C}$ for $5 \mathrm{~min}$. The PCR product was kept on the temperature of $4{ }^{\circ} \mathrm{C}$ for $25 \mathrm{~min}$. The forward primer was 5'-TAGGGGAGGGTGGAAAATGGA-3' and the reverse primer was 5'-GACACCTACTCAGACAATGCG-3' (Yao et al 1996). The position of primer Forward and Reverse in PCR product of GH gene shows in Figure 1.

\section{Data Analysis}

The result of sequence of GH gene fragment of Aceh cattle was analyzed by Molecular Evolutionary Genetic Analysis (MEGA4) software program with alignment explorer/clustal method (Kumar \& Tamura, 2006), also compared to the sequence in GenBank (M57764). The analysis was to ensure that the analyzed sequence is the $\mathrm{GH}$ gene fragment, and to find out the existence of mutation in GH gene and the sequence of nucleotide. Data was analyzed by allele frequency (Nei, 1987). The gene frequencies were calculated by counting methods as:

$\mathrm{p}=[2(\mathrm{AA})+(\mathrm{Aa})] / 2 \mathrm{~N} ; \mathrm{q}=[2(\mathrm{aa})+(\mathrm{Aa})] / 2 \mathrm{~N}$

The genotype frequency was analyzed by Hardy -Weinberg:

$$
x^{2}=\left[\sum_{i=1}^{\mathrm{n}}(O-E)^{2}\right] / E
$$

Note: $X^{2}=$ Chi-square test

$\mathrm{O}=$ total of genotype observed $-\mathrm{i}$

$\mathrm{E}=$ total of genotype expected $-\mathrm{i}$

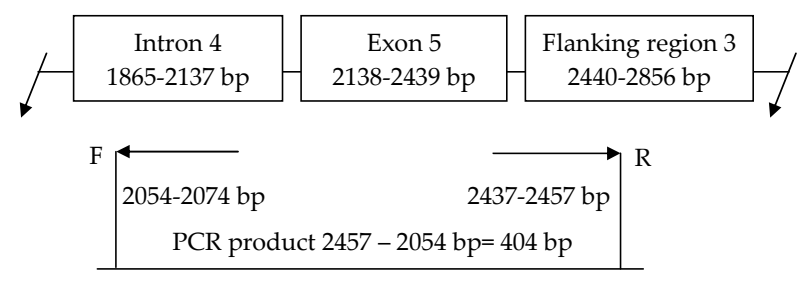

Figure 1. The position of primer Forward and Reverse in PCR product of GH gene 


\section{RESULTS AND DISCUSSION}

\section{The Frequency Allele and SNPs Sequence Analysis}

The samples which were managed to be sequenced were forty four samples from Banda Aceh (9), Saree (12), and Indrapuri (23). The failure to sequence was caused by unsuccessful amplification, limited number of DNA, and too many peak duplication on sequence graphics. The analysis on the diversity of nucleotide sequence was conducted using MEGA programs after the sequence of Aceh cattle DNA was paralelled with the sample of comparison sequence from Gen Bank (M57764). The PCR product of GH AluI locus (404 bp) detected by agarose gel and the alignment of Aceh cattle can be seen in Figure 3 and 4, respectively.

The result of GH gene nucleotide sequence in Aceh cattle, the change from $C$ to $G$ nucleotide on position $2141 \mathrm{bp}$ was not found. Jakaria \& Noor (2011) also found that there was no mutation on position $2141 \mathrm{bp}$ in Bali cattle. However, on position 2291 bp (Figure 4) A nucleotide turned into $C$ nucleotide. This result is similar to that of Ge et al. (2003) on Angus cattle.

Hecht \& Geldermann (1996) compared the sequence from exon 5 areas which clamped $\mathrm{GH}$ gene on eight cattle offspring and found an insert/an omission of two nucleotide and five SNPs in the area of putative promoter, including three SNPs which were identified

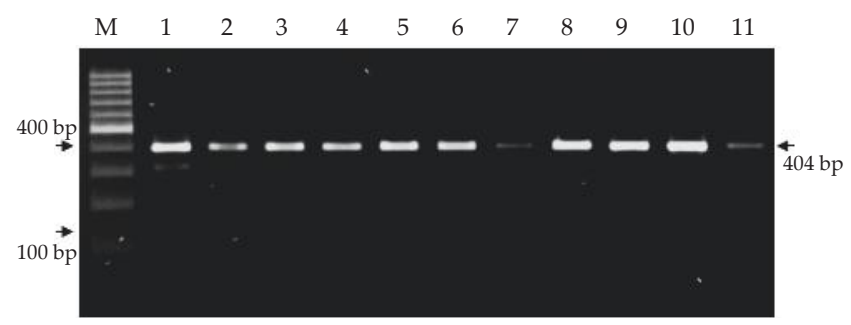

Figure 2. The visualization of amplification GH gene using agarose gel 1.5\% (M: marker $100 \mathrm{bp}, 1-11$ : research samples).
2041 ttctccaage etgtagggga gggtggaaa tggagcgggc aggagggagc tgctcctgag

2101 ggccettcgg ectetctgtc tetcectcce ttggcaggag ctggaagatg gcaccecceg 2161 ggctgggcag atectcaagc agacstatga caaatttgac asaaacatgc gcagtgacga 2221 cgcgctgct $c_{\downarrow}$ aagaactacg gtctgctctc ctgcttccgg aaggacctgc ataagacgga 2281 gacgtacctg agggtcatga agtgecgecg cttcggggag gecagctgtg ccttctagtt 2341 gccagccate tgttgtttgc ccctececcg tgcettcett gaccetggaa ggtgccactc 2401 ccactgtcct ttectaataa aatgaggaaa ttgcatcgca ttgtctgagt aggtgtcatt

Figure 3. The position of primer Forward and Reverse in sequence product and the mutation position in $2230 \mathrm{bp}$

in Angus cattle. Several polymorphisms had been identified in exon five from cattle GH gene in various cattle offspring (Table 1).

The effect of some GH gene polymorphisms has been widely studied on cattle (Switonski, 2002) and there are several polymorphisms that can be marked using different restriction enzymes. The presence of $A l u \mathrm{I}$ site as a divider indicates the existence of leucine amino acid (L) in the position of 127 in GH polypeptide chain, whereas the absence of this site indicates the presence of valine $(\mathrm{V})$ in the same position. This polymorphism can be used as a marker but there are not many researches on the use of marker or this genetic marker in the characteristics of production on livestock.

$\mathrm{GH}$ polymorphism is also known as AluI RFLP, which was previously investigated by Lucy et al. (1993) and Jakaria et al. (2007). In Pesisir cattle, C nucleotide turned into $G$ nucleotide while in Bali cattle there was not mutation on the fifth exon from $\mathrm{GH}$ gene. The

Table 1 . The variation of sequence which has been identified in the exon from GH gene on cattle

\begin{tabular}{cccc}
\hline Position & $\begin{array}{c}\text { Mutation } \\
\text { change }\end{array}$ & $\begin{array}{c}\text { Cattle } \\
\text { type }\end{array}$ & Reference \\
\hline 2291 & $\mathrm{~A}>\mathrm{C}$ & Angus, Aceh & $\begin{array}{l}\text { Ge et al. (2003), } \\
\text { Research result } \\
2230\end{array}$ \\
\hline
\end{tabular}

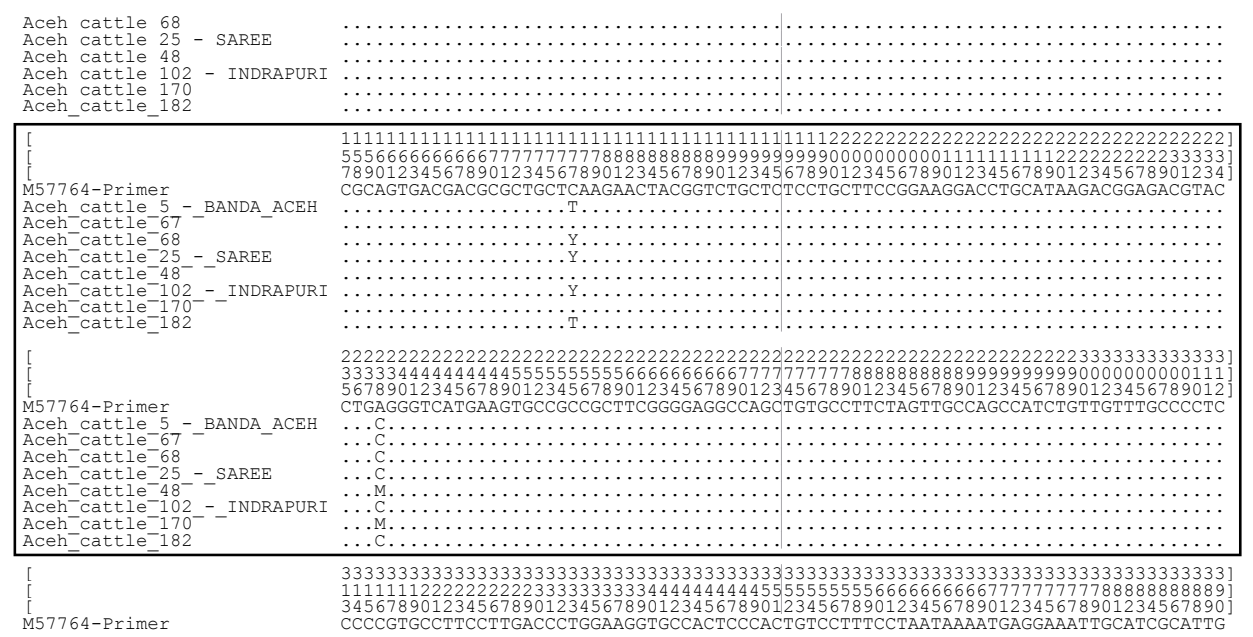

Figure 4. The alignment of Aceh cattle with Gen Bank (M57764); Y nucleotide (C \& T), M nucleotide (A \& C). 
Table 2. Genotype and frequency of allele from GH gene on Aceh cattle on position of $2291 \mathrm{bp}$

\begin{tabular}{lcccccccc}
\hline & \multicolumn{3}{c}{ Genotype } & & \multicolumn{3}{c}{ Allele } \\
\cline { 2 - 4 } \cline { 6 - 8 } Population & AA & AC & CC & & A & C & $X^{2}$ \\
\hline Banda & 0 & 0 & $1.00(9)$ & & 0 & 1.00 & \\
Aceh (9) & & & & & & \\
Saree (12) & $0.13(2)$ & $0.12(1)$ & $0.75(9)$ & & 0.12 & 0.88 & ns \\
Indrapuri & $0.05(1)$ & $0.05(1)$ & $0.90(21)$ & & 0.07 & 0.93 & ns \\
$(23)$ & & & & & & \\
Total (44) & $0.07(3)$ & $0.04(2)$ & $0.89(39)$ & & 0.05 & 0.95 & ns \\
\hline
\end{tabular}

Note: (ns): not differ significantly $(\mathrm{P}>0.05)$.

Table 3. Genotype and frequency of allele from GH gene on Aceh cattle on position of $2230 \mathrm{bp}$

\begin{tabular}{ccccccccc}
\hline & \multicolumn{3}{c}{ Genotype } & & \multicolumn{3}{c}{ Allele } \\
\cline { 2 - 4 } \cline { 6 - 8 } Population & CC & CT & TT & & C & T & $X^{2}$ \\
\hline $\begin{array}{c}\text { Banda Aceh } \\
(9)\end{array}$ & $0.56(5)$ & $0.22(2)$ & $0.22(2)$ & & 0.67 & 0.33 & ns \\
Saree (12) & $0.42(5)$ & $0.58(7)$ & 0 & & 0.71 & 0.29 & \\
$\begin{array}{c}\text { Indrapuri } \\
(23)\end{array}$ & $0.26(6)$ & $0.57(13)$ & $0.17(4)$ & & 0.55 & 0.45 & ns \\
Total (44) & $0.36(16)$ & $0.50(22)$ & $0.14(6)$ & & 0.61 & 0.39 & ns \\
\hline
\end{tabular}

Note: (ns): not differ significantly ( $\mathrm{P}>0.05)$.

change of C-G nucleotide on the fifth exon from GH gene, which yields two alleles on GH gene called leucine and valine in the position of 127. Lucy et al. (1993) reported that the cattle produced less milk when it was related to $\mathrm{GH}$ valine variant on Holstein cattle.

The population of Aceh cattle from Banda Aceh only had CC genotype, whereas AA, AC, and CC genotype were possessed by those from Saree and Indrapuri. CC genotype has higher value than $\mathrm{AA}$ and AC genotype in the whole sample of Aceh cattle population (Banda Aceh, Saree, and Indrapuri), so that the frequency of $\mathrm{C}$ allele is higher than that of A allele (Table 2). Chi-square test showed no significant differences in genotypic frequencies for three populations of Aceh cattle in the mutation position on $2291 \mathrm{bp}$. It means that the genotypic frequencies were still in the Hardy-Weinberg equilibrium. This condition was caused by no exchange of alleles between population, infinite population size, and no selective pressure for or against any genotypes.

The research result on the population of Aceh cattle on GH gene showed that there was one point of new mutation on exon five on the position of 2230 (Figure 3) in which $\mathrm{C}$ nucleotide turned into $\mathrm{T}$ nucleotide, and a Silent Mutation occurred, in which Leucine turned into Leucine (CTC - CTT).

TT genotype was not possessed by the population of Aceh cattle from Saree, but those from Banda Aceh and Indrapuri had one, with the smaller value from CC and CT genotype (Table 3). CC genotype had higher value than $\mathrm{CT}$ genotype on the population of Aceh cattle from Banda Aceh; on the other hand, CT genotype had higher value than CC genotype on the population of Aceh cattle from Indrapuri. Chi-square test showed no significant differences in genotypic frequencies for three populations of Aceh cattle in the mutation position on $2230 \mathrm{bp}$. It also means that the genotypic frequencies were still in the Hardy-Weinberg equilibrium. This condition was caused by both allele and genotype frequencies in a population remain constant. Mutation and selection did not occur in this population.

\section{CONCLUSION}

There is one new SNP $(\mathrm{C}>\mathrm{T})$ in exon five of Aceh cattle on the position of $2230 \mathrm{bp}$. The genotypic frequencies in the position $2230 \mathrm{bp}$ and $2141 \mathrm{bp}$ are still in the Hardy-Weinberg equilibrium. It is necessary to conduct a further research on other local cattle populations to see polymorphisms on the existing local cattle in Indonesia especially in Aceh cattle as well as the effects of the other polymorphism in the growth hormone exon five.

\section{ACKNOWLEDGMENT}

The authors would like to thank the Directorate General of Higher Education, Ministry of Education and Culture, Republic of Indonesia for funding of the research in Sandwich Program 2009/2010. We also thank to all colleagues in BPTU Indrapuri for their help in collecting sample.

\section{REFERENCES}

Dybus, A. 2002. Association of Growth Hormone (GH) and Prolactin RL gene polymorphisms with milk production traits in Polish Black and White cattle. Anim. Sci. Paper Report 20:203-212.

Ge, W., M. E. Davis, H. C. Hines, K. M. Irvin, \& R. C. M. Simmen. 2003. Association of a single nucleotide polymorphisms in growth hormone and growth hormone receptor genes with blood serum insulin-like growth factor I concentration in Angus cattle. J Anim. Sci. 81:641-648.

Hecht, C. \& H. Geldermann. 1996. Variants within the 5'-flanking region and intron I of the bovine growth hormone gene. Anim. Genet. 27:329-332.

Jakaria, D. Duryadi, R. R. Noor, B. Tappa, \& H. Martojo. 2007. Evaluasi keragaman gen hormon pertumbuhan $(\mathrm{GH})$ pada sapi pesisir Sumatera Barat menggunakan penciri PCRRFLP. Med. Pet. 30: 1-10.

Jakaria \& R. R. Noor. 2011. Analysis on AluI growth hormone (GH Alu-I) gene in Bali cattle. J. Indonesian Trop. Anim. Agric 36: 78-82.

Kumar, S. \& K. Tamura. 2006. MEGA4. Molecular Evolutionary Genetic Analysis Software. Arizona State University, Arizona USA.

Lagziel, A., S. Denise, O. Hanotte, S. Dhara, V.Glazko, A. Broadhead, R. Davoli, V. Russo, \& M. Soller. 2000. Geographic and breed distribution of an MspI PCR-RFLP in the bovine growth hormone (bGH) gene. Anim. Genet. 31:210213. http://dx.doi.org/10.1046/j.1365-2052.2000.00622.x

Lucy, M. C., S. D. Hauser, P. J. Eppard, G. G. Krivi, J. H. Clark, D. E. Baumen, \& R. J. Collier. 1993. Variant of somatotropin allele in cattle: Gene frequencies in major dairy breeds and associated milk production. Domest. Anim. Endocrino. 10:325-333. http://dx.doi.org/10.1016/0739-7240(93)90036-B

Nei, M. 1987. Molecular Evolutionary Genetics. Columbia Uni- 
versity Press, New York.

Sambrook, J., E. F. Fritsch, \& T. Maniatis. 1989. Molecular Cloning: A laboratory Manual. 2nd Ed. Cold Spring Harbor Laboratory Press, USA.

Sari, E. M, R. R. Noor, C. Sumantri, \& E. Trimargawati. 2010. Identification of genotype DNA microsatellite in association with performance of Indonesian Aceh cattle. Journal of Genetic Engineering and Biotechnology 8: 43-51.

Sutarno, A., A. Junaidi, Purwoko, \& N. I. Lelana. 2002. Identification and characterization of the polymorphic growth hormone gene of the Bali cattle, the Madura cattle and Ongole cattle. Biodiversitas 3:169-173.

Switonski, M. 2002. Molecular genetics in beef breeding. Anim Sci Genet. Paper Rep 20:7-18
Yao, J. S. E. Aggrey, D. Zadworny, J. F. Hayes, U. Kuhnlein. 1996. Sequence variation in the bovine growth hormone gene characterized by Single Strand Conformation Polymorphism (SSCP) analysis and their association with milk production traits in Holstein. Genetic 144: 1809-1816.

Zakizadeh, S. G. Rahimi, S. R. Mirae-Ashtiani, A. NejatiJvareni, M. Moradi-Shahrbabak, P. Reineeke, M. Reissmann, A. A. Masoudi, C. Amirinia, \& A. A. Mirhadi. 2006. Analysis of bovine growth hormone gene polymorphism in three Iranian native breeds and Holstein cattle by RFLPPCR. Biotech 5:385-390. http://dx.doi.org/10.3923/biotech.2006.385.390 